Mikhail Antonov*

\title{
Law and Memory Politics in Russia
}

\begin{abstract}
Legal possibilities for historical interpretations in Russia are more flexible than in many other post-communist countries. However, this extent of freedom of opinion became an irritating factor for the authoritarian regime in the $2010 \mathrm{~s}$ : the freedom to evaluate historical facts is an obstacle for imposing ideology everywhere. Under the presidency of Dmitry Medvedev, a number of tools were introduced into Russian law to secure the state control in school education. At the international level, Russia started to actively fight against 'falsifications of history' and employed a rich arsenal of ideological tools to defend the Soviet interpretation of World War II. In the domestic law as well, new corpuses delicti were introduced in criminal and administrative law to defend the Soviet history from attempted falsifications. This development coincided with the general trend to exceptionalism characterized by the legislation on foreign agents, or restrictive amendments in the anti-extremist law. The present paper will attempt to analyze this development and its ideological and legal contexts.
\end{abstract}

\section{Introduction}

The present paper examines the evolution of memory politics in post-Soviet Russia and provides a short overview of the normative legal framework of this politics. There are two major axes around which the official memory politics is regulated in Russian law: the great narrative about the Second World War, and the patriotic education of the youth. The first axis is based on the $1995 \mathrm{Law}^{1}$ which commemorates the decisive role of the Soviet Union in the Second World War and prohibits calling this role into question. Until the mid-2000 s, this Law remained the only keystone in the normative framework of Russian memory politics.

There were various reasons for this disregard for normative regulation of memory politics in Russia. On the one hand, the Yeltsin government was reluctant to support the "great narratives" about the 1917 Revolution, the 1941-1945 War and other facts of the Soviet history, as these facts were the legitimation basis for its adversaries: communists as well as traditionalists. On the other hand, the idea of control over of

* Mikhail Antonov, PhD, Associate Professor, National Research University Higher School of Economics (St. Petersburg, Russia), Law Faculty, Department of Theory and History of Law and State. This article has been prepared during a fellowship at the Institute of Eastern European and Comparative Law at the University of Cologne with the financial support of the Alexander von Humboldt Foundation (Alexander von Humboldt-Stiftung).

1 Федеральный закон (19.5.1995, №.80-Ф3) “Об увековечении Победы советского народа в Великой Отечественной войне 1941-1945 годов" [Federal Law “On the Perpetuation of the Victory of the Soviet People in the Great Patriotic War 1941-1945"]. 
memory politics could be easily associated with the despicable Soviet experience of ideological censorship and therefore was obnoxious to the liberals from Yeltsin's government.

The situation started to change slowly only from the first presidency of Putin onward. Initially, these changes were not directly enshrined in the legislation. When the government felt that its interference was required to ban certain historical narratives dangerous for the regime, the authorities could easily use the legal gateways provided for in the anti-extremist legislation that was adopted shortly after Putin came to power. $^{2}$ This reliance on the anti-extremist legislation in dealing with memory politics is the main strategy of the authorities until our days.

Over the time, the Kremlin has learned to appreciate the importance of historical interpretations for maintaining its legitimacy inside the country and for the expansion of its soft power in international politics. Toward the end of the $2000 \mathrm{~s}$, a number of legal regulations officially proclaimed the main objectives of the memory politics in the field of education. Special attention was devoted to school textbooks on Russia's $20^{\text {th }}$ century history. The first governmental attempts to formulate memory politics in the educational sphere were incoherent. On the one hand, the Soviet past received different evaluations in the circles around the Presidential Administration. On the other hand, this past remained then - and still remains - a very controversial subject matter for Russians, so that evaluating certain historical events, such as the 2017 October Revolution, can be detrimental for legitimacy. On the other hand, as O. Malinova rightly observes, "the symbol of October is not relevant as a tool for justification or for criticism of the current political course". ${ }^{3}$ The same can be said also about many other episodes of Soviet history.

On the international level, Russia's memory politics was more coherent and pragmatic. Russia consistently asserted its role of protector of mankind against the rehabilitation of Nazism, and successfully gathered some symbolic capital on it for promoting its geopolitical interests. Strategically referring to this role, Russia has not infrequently justified its interferences into the internal affairs of its neighbors (especially, Ukraine and the Baltic states). Exemplarily, this anti-Nazism narrative was utilized to vindicate the annexation of Crimea and the support of the Donbass separatists: reasoning that the population of these regions does not want to live under the rule of the Kyiv authorities, which rehabilitate controversial historical personages, such as Bandera or Shukhevych, who fought against the Soviet Army alongside the Nazis.

The 2013 amendments, which aimed to protect religious feelings of believers of the "traditional" religious denominations of Russia, ${ }^{4}$ became - along with the anti-extremist legislation - another major legal gateway for managing the state's memory po-

2 Федеральный закон (25.7.2002, No.114-Ф3) “О противодействии экстремистской деятельности" [Federal Law "On Counteracting Extremist Activities"].

3 О.Ю. Малинова, Актуальное прошлое: Символическая политика властвующей элиты и дилеммы российской идентичности, Москва: Политическая энциклопедия, 2015, p. 80.

4 Федеральный закон (29.6.2013, No.136-Ф3) “О внесении изменений в статью 148 Уголовного кодекса РФ и отдельные законодательные акты РФ в целях противодействия оскорблению религиозных убеждений и чувств граждан" [Federal Law "On Bringing Amendments in Article 148 of the RF Criminal Code and in Other 
litics. These amendments implicitly introduced a number of limitations on the interpretation of historical facts which directly or indirectly touched on religious sentiments.

On the wave of patriotic moods after the 2014 annexation of Crimea, and seeking to protect its symbolic sphere against attacks from the West, Russia adopted a number of laws that considerably narrowed the freedom of evaluation and opinion in judgments about historical facts. The 2014 legislative amendments, under the banner of stronger prohibition of rehabilitation of Nazism, banned any attempts to cast doubts on the decisive role of the USSR in fighting Nazism or to justify the national liberation movements which collaborated with the Nazis in the years of the Second World War. ${ }^{5}$

These legal gateways to prevent rehabilitation of Nazism, to protect religious feelings and to counteract extremism provide the Russian authorities with a powerful combination of legal tools to interfere with historical interpretations. These interferences do not seek to establish any historical truth: they are rather focused on reaching objectives of the state policies in other fields, and are - from this standpoint - purely ideological. ${ }^{6}$ There is an array of such objectives, among which are "maintenance and strengthening of national identity", "prevention of separatism and regionalism", 8 or "development of spiritual potential of personality". 9 Unsurprisingly, these objectives lead to the conservative reading of history, which prompts the state to foster such historical interpretations that are in line with the prevailing communitarian morality and the ideal of a strong state.

\section{Historical perspective and its normative contexts}

Memory politics was central for Soviet ideology and represented one of the cornerstones of its foundational narratives. These latter were centered on the past, with its great events and heroic personalities. The 1917 Bolshevik revolution, the Second World War, Vladimir Lenin and the entire pantheon of the Soviet leaders were among the

Legislative Acts of the RF in Order to Counteract Insults of Religious Convictions and Feelings of Citizens"].

5 Федеральный закон (4.11.2014, No.332-Ф3) “О внесении изменений в статью 6 Федерального закона "Об увековечении Победы советского народа в Великой Отечественной войне 1941-1945 годов" и статью 20.3 Кодекса РФ об административных правонарушениях" [Federal Law "On Bringing Amendments in Article 6 of Federal Law "On the Perpetuation of the Victory of the Soviet People in the Great Patriotic War 1941-1945" and in Article 20.13 of the RF Code of Administrative Offences"].

6 See: А.И. Миллер, “Россия: власть и история”, Pro et Contra (2009), No.3-4, p. 8.

7 Указ Президента РФ (31.12.2015, No.683) “О Стратегии национальной безопасности РФ" [Decree of the RF President "On the Strategy of National Security of the RF"].

8 Указ Президента РФ (19.12.2012, No.1666) “О Стратегии государственной национальной политики РФ на период до 2025 года" [Decree of the RF President "On the Strategy of the State National Politics of the RF for the Period Until 2025"].

9 Распоряжение Правительства РФ (29.5.2015, No.996-p) “Об утверждении Стратегии развития воспитания в РФ на период до 2025" [Regulation of the RF Government “On the Approval of the Strategy of Development of Education in the RF for the Period Until 2025"]. 
main reference points of this ideological symbolism. This attitude was easily perceptible in the Soviet philosophy of history which presupposed that historical events in Russia had developed under the objective laws of history before Lenin and other great heroes of the Revolution managed to move Soviet Russia and its allies into a new historical eon, making the "leap from the kingdom of necessity to the kingdom of freedom. ${ }^{10}$ In what concerns both these historical eons (before and after 1917) alternative readings of history were excluded - the pre-1917 history was determined by the objective laws discovered by Marx and Engels, and could be interpreted only in the light of these laws (and only in the way these laws were interpreted in the Soviet ideology), while the post-1917 history was so inextricably intertwined into the Marxist-Leninist ideology that any deviating historical interpretations would inevitably mean a challenge to this ideology. Expectedly, the Soviet law enforcement system did not tolerate any attempts to challenge this historical framework of Soviet identity: thousands were sent to prisons because of household jokes about Lenin and other great men or historical events of the 1917 Revolution in the Brezhnev era, let alone thousands of those who had been repressed for the same cause during the purges in the Stalin era. Even if no memory politics was established in Soviet law de jure, it was consistently carried out de facto by the secret services, courts and law enforcement agencies. ${ }^{11}$

Perestroika ruined the Soviet memory politics and seemingly excluded other ideologies to take its place. In the narratives of the late $1980 \mathrm{~s}$, glasnost' (ideological openness) commonly formed a pair concept with perestroika, so that the latter was not thinkable for many without the former. The abolition of ideological censorship was unconditioned to the extent that practically any views and evaluations (including racist, anti-Semite and similar ones) could be expressed with impunity.

As the Constitutional Court of the Russian Federation argued in the 1992 milestone CPSU (Communist Party of the Soviet Union) case, there can be no limitation on political opinions and convictions in a democratic state, so that the Communist ideology cannot be outlawed. Basing on this argumentation, the Constitutional Court of the Russian Federation partly invalidated Yeltsin's decree on disbanding the CPSU and excluded responsibility of the CPSU for the past. ${ }^{12}$ This ruling meant that - differently to many other countries of the ex-Warsaw block - Russia was not to reconsider its past and was resolute to abstain from naming and shaming those who are guilty for atrocities of the Soviet regime. ${ }^{13}$ Symptomatically, the 1991 Law dealing with the rehabilitation of victims of the Soviet regime ${ }^{14}$ did not condemn the Soviet

10 Friedrich Engels, Anti-Dühring, in: Collected Works by Karl Marx and Friedrich Engels, 50 vols. (New York: International Publishers, 1987), vol. 25, p. 270.

11 One can naturally argue that the NKVD and KGB repressions were contrary to the letter of the Soviet constitutional law which proclaimed freedom of expression as basic rights of Soviet citizens, but discussing the discrepancies between the law-in-books and the law-inaction of the Soviet Union is not the purpose of this paper (see author's paper: "Legal Realism in Soviet and Russian Jurisprudence", (2018), No.43, p. 483-518).

12 Постановление Конституционного Суда РФ (30.11.1992, No.9-П).

13 J. Henderson, "Making a Drama out of a Crisis: The Russian Constitutional Court and the Case of the Communist Party of the Soviet Union", King's College Law Journal (2008), No. 3 (19), p. 489-506.

14 Закон РФ (18.10.1991, No.1761-1) “О реабилитации жертв политических репрессий” [Law of the RF "On the Rehabilitation of Victims of Political Repressions"]. 
ideology as such, but condemned in general totalitarian practices to punish people because of political and religious convictions (Preamble). ${ }^{15}$

The provisions of the 1993 RF Constitution confirmed this trend toward historical and ideological neutrality. Article 13 directly prohibits imposing state or any other obligatory ideology in Russia. Ideological pluralism was interpreted by the Constitutional Court of the Russian Federation in its 2004 ruling in the sense that the law can only exceptionally impose formal limitations and solely with the aim to avoid discrimination and other serious violations of human rights. ${ }^{16}$ The jurisprudence of the Constitutional Court of the Russian Federation accommodated no room for introducing memory politics as contrary to ideological pluralism, although there are many voices calling to exclude the ban on state ideology from the Constitution. ${ }^{17}$

During the $1990 \mathrm{~s}$, memory politics was not a serious legal issue in Russia; the state was reluctant to enter into an evaluation of the past, and the main message of the state policies was the reconciliation with the past. ${ }^{18}$ Even the Law "On the Perpetuation of the Victory of the Soviet People" of 1995 enshrined no clear memory politics: this law, until recently, limited itself to condemning Nazism and Nazi criminals. The situation slowly

15 In December 2019, the Constitutional Court of the Russian Federation had to deal with the delicate issue of responsibility of Russia for the crimes of the Soviet regime. In its Ruling No 39-П (10 December 2019), the Court considers the legal nature of the obligation of the Russian state to provide housing to victims of political repressions under the 1991 Law. Striking down the provisions of a law of the City of Moscow which complicated access to the right to this housing right for victims of political repressions, the Court reasoned that Russia, as a legal successor of the USSR, shall indemnify the victims of Soviet repressions (para. 2). In his dissident opinion, Justice Konstantin Aranovskiy argued against shifting "liability for repressive and terrorist actions of the Communist-Soviet state" on Russia. He also strongly disagreed with the majority opinion that Russia is a successor of the USSR in all aspects. This Ruling and its reasoning has revived polemics between Russian lawyers about the nature of succession (continuation) between the USSR and Russia, and in particular about legal and moral responsibility of Russia for the Soviet state and its crimes.

16 Постановление Конституционного Суда РФ (15.12.2004, o.18-П).

17 Е.g., С.А. Авакьян, Властеотношения: закономерности существования, субъективизм регулирования и правоприменения, Конституционное и муниципальное право (2018), No. 5, p. 6; О.Е. Кутафин, Российский конституционализм, Москва: Норма, 2008, p. 378-379. In May 2019, at a conference convened by the RF Constitutional Court, T. Khabrie$v a$, director of the Russian Institute of Legislation and Comparative Law (the governmental think tank which prepares legislative draft-bills), called for the introduction of a state ideology based on "genetic values of Russian people" into the Constitution of the Russian Federation, https://ria.ru/20190514/1553478995.html.

18 Illustrating this tendency, the "Day of the October Revolution" ( $7^{\text {th }}$ of November) was renamed in 1996 into the "Day of National Consent and Reconciliation" (Указ Президента РФ (7.11.1996, No.1537).

“О Дне согласия и примирения" [Decree of the RF President "On the Day of National Consent and Reconciliation"]. Later, this day became also one of the days of military glory of Russia (to commemorate the military parade in Moscow in 1941): Федеральный закон (24.12.2004, No.200) “О внесении изменений в статью 1 Федерального закона “О днях воинской славы (победных днях) России” [Federal Law “On Bringing Amendments in Article 1 of the Federal Law "On the Days of Military Glory (Victory Days) of Russia"]. Similarly, the "Day of Soviet Army" ( $23^{\text {rd }}$ of February) was renamed into the "Day of Defensor of Homeland" in 1995, still remaining a public holiday until now. 
started to change in Putin's era, from 2000 onward. Restoring the "great country" (velikoderzhavnost') could not be practically undertaken without making clearer links with the past which is a rich source for fostering legitimacy everywhere.

Reviving the Soviet anthem in December 2000, albeit with new lyrics, was one of the symbolic steps of the new government in its reappraisal of the Soviet past. ${ }^{19}$ Another emblematic episode was Putin's veto in 2007 on the draft bill that imposed limitations on the utilization of the Soviet flag and other Soviet symbols during official ceremonies. $^{20}$ Nonetheless, this symbolism in governmental politics was far from being coherent - along with praising events from the Soviet history, the official narratives also tended to attach strong value to the glorious imperial past with its conservative, contra-revolutionary heroes and discourses. As examples of this counter-tendency can be mentioned: the solemn return and reburial of the remains of the famous general of the White Army, Anton Denikin, in $2005^{21}$ and of the conservative thinker Ivan Ilyin, or the rehabilitation of the last emperor Nicholas (Nikolai) II and his family by a ruling of Russia's Supreme Court in 2008 which put the end to the long legal controversy about his historical personage. ${ }^{22}$

Until recently, the creation of an articulated memory politics has not been on the agenda of the Russian authorities. ${ }^{23}$ O. Malinova justly evaluates that

in Russia the collective past is rather the object of coincidental use and not the object of purposeful construction. It is evident that the politicians acting on behalf of the Russian state prefer not to touch on the difficult past and try, as far as possible, to avoid definitive formulations in evaluations of those historical events, processes and personalities which raise ardent contestations in the society. ${ }^{24}$

Despite the emotional attractiveness of the memory politics based on the 1995 Law "On the Perpetuation of the Victory of the Soviet People", this basis is not sufficient to cover all the events of Russian history. Until the $2000 \mathrm{~s}$, the authorities did not demonstrate direct involvement into coining memory politics as to the historical

19 Указ Президента РФ (30.12.2000, No.2110), “О тексте Государственного гимна $P \Phi "$ [Decree of the RF President "On the Text of the State Anthem of the RF"], shortly thereafter replaced by Федеральный конституционный закон (22.3.2001, №.2-ФК3) “О внесении изменений и дополнения в Федеральный конституционный закон "О Государственном гимне РФ” [Federal Constitutional Law “On Bringing Amendments and Additions into the Federal Constitutional Law "On the State Anthem of the RF"].

20 Путин отклонил закон о Знамени Победы, принятый единороссами в Госдуме, available at: http://www.newsru.com/russia/20apr2007/flag3.html.

21 This reburial was carried out in pursuance of the Order of the RF President (5.10.2004, No.ПР-1808).

22 Ruling of the Presidium of the Supreme Court of the Russian Federation (1.10.2008, No.274П08).

23 Г.А. Бордюгов/В.М. Бухараев, Вчерашнее завтра: как национальные истории писались в СССР и как пишутся теперь (Москва: АИРО-XXI, 2011); Н.E. Копосов, Память строгого режима: История и политика в России (Москва: Новое литературное обозрение, 2011).

24 О.Ю. Малинова, Политическое использование прошлого как инструмент символической политики: эволюция дискурса властвующей элиты в постсоветской России, Политическая экспертиза: ПОЛИТЭКС (2012), No.8(4), p. 198. 
events which did not concern the Second World War. Soon it turned out that identitarian discourses informed by historical facts can stir separatist or other movements and ideas dangerous for the political regime and undermining its legitimacy.

In Russian law these discourses are, first of all, controlled by the anti-extremist legislation. Pursuant to the Federal Law No.114-FZ "On Counteracting of the Extremist Activities in Russia" of 2003, the definition of "extremism" involves various criteria among which are such as: "propaganda of national, religious, social or linguistic superiority". This statutory criterion of extremism inevitably relies on certain interpretations of historical facts. By way of example, a number of Russian journalists, bloggers and activists were punished under the anti-extremist law for supporting the Ukrainian versions of history in what concerns the deportation of Crimean Tartars in 1944, the Holodomor, the evaluation of the activities of Ukrainian collaborationists in 1941-1945, and other sensitive issues between Russian and Ukrainian authorities. ${ }^{25}$ The events of the $20^{\text {th }}$ century remain the central point in these informational wars, but ideological battles about history can sometimes go far back to the past, like the contradictory narratives about the early Russian state (Kievan Rus'), whose political continuity is vehemently contested between Russia and Ukraine.

The Federal Law No.114-FZ did not remain the only legal gateway for an indirect shaping of memory politics. The 2012 Law on Foreign Agents ${ }^{26}$ did not directly intend to take issue with historical interpretations. Indirectly, this Law affected a number of Russian non-profit organizations which promote principles that contradict the official conservative narratives: such as non-discrimination of LGBT, democracy, gender equality, and, unsurprisingly, several "Memorial" organizations that investigate the crimes of the Soviet regime, including the mass repressions. In 2014 the first "Memorial" organization in Moscow was brought on the list of foreign agents by the Ministry of Justice, with this decision being confirmed by courts. ${ }^{27}$ This practice was followed in other regions of Russia.

A similar legal technique (vague criteria which finally support certain interpretations of historical facts) has been used in the legislative amendments in 2014 which prohibited insulting religious feelings of the prevailing denominations. Although, there is no direct regulation on memory politics in these amendments, indirectly they did impose a number of important indirect restrictions in this field, as far as religious events and beliefs can be commented against the backdrop of historical facts. In particular, this legal gateway was utilized by churchmen to oppose staging the interpretation of Wagner's opera "Tannhäuser" in Novosibirsk in 2015, ridiculing Jesus Christ as

25 As one of the illustrative examples, the 2017 criminal charges against the director of the Ukrainian library in Moscow, Natalia Sharina, can be cited.

26 Федеральный закон (20.7.2012, No.121-Ф3) “О внесении изменений в отдельные законодательные акты Российской Федерации в части регулирования деятельности некоммерческих организаций, выполняющих функции иностранного агента" от [Federal Law "On Bringing Amendments in Particular Legislative Acts of the RF Concerning the Regulation of Activities of Non-Commercial Organizations that Carry out Functions of a Foreign Agent"].

27 Суд признал иностранным агентом правозащитный центр Мемориал, Московский комсомолец (23.5.2014), https://www.mk.ru/social/2014/05/23/cud-priznal-inostrannyimagentom-pravozaschitnyiy-tsentr-memorial.html. 
a historical personage, or to prevent screening of Alexei Uchitel's film "Matilda" in 2017 about a love affair of Emperor Nicholas (Nikolai) II who was canonized by the Russian Orthodox Church in 2000.

\section{Patriotism and anti-Nazism as key messages of memory politics}

Even if the authorities are reluctant to lose points of popular support because of delving into historical speculations, the past and its evaluations are not irrelevant to them. Propositions about managing official memory politics have been discussed already in the 1990 s. $^{28}$ As demonstrated above, the main concerns of Russian policymakers were usually connected with evaluations of the Second World War and its aftermath. A large number of polemical remarks have been made by the Russian authorities with criticism of the "Western reading" of history which amounted the importance of fighting against the Nazis and their allies in North Africa or in Pacific Ocean with the battles of Moscow or Stalingrad, or equated the Soviet "occupation" with the Nazi domination in Central Europe or in Baltic states. ${ }^{29}$

Unsurprisingly, these concerns prompted the authorities to more active political engagements. In 2007, the President decided to create the Russian Military Historical Society funded by the state and tasked to prevent "distortions of Russian military history". ${ }^{30}$ The contents of school textbooks on contemporary history became the main target for contestations of the historical past. In a meeting with schoolteachers in 2007 (around the same time when he vetoed the law on the prohibition of Soviet symbols [see above]), President Putin expressed his deep concerns about "historical objectivity" about Soviet history. Putin's positive assessment of the Soviet past was expressed then in his notorious diction about the end of the Soviet Union as "one of the major geopolitical catastrophes in the world". ${ }^{31}$ During that meeting, he reproached Russian historians that "there are practically no textbooks that deeply and objectively reflect the events of the recent history of our homeland".

The reaction was not long in coming: shortly thereafter, the controversial textbook on history appeared, edited by the conservative political thinker Alexander Filippov, ${ }^{32}$ in

28 В.В. Титов, Политика памяти и формирование национально-государственной идентичности: российский опыт и новые тенденции (Москва: Ваш формат, 2017), p. 60-71.

29 A.C. Сенявский/E. С. Сенявская, Вторая мировая война и историческая память: образ прошлого в контексте современной геополитики, Вестник МГИМО, История (2009), Special Issue, p. 299-310.

30 Указ Президента РФ (29.12.2012, No.1710) “О создании Общероссийской общественногосударственной организации 'Российское военно-историческое общество”' [Decree of the RF President "On the Creation of the All-Russia Social and State Organisation 'Russian Military-Historical Society"'].

31 Выступление Президента РФ В.В. Путина на встрече с делегатами Всероссийской конференции преподавателей гуманитарных и общественных наук 21 июня 2007 г., Преподавание истории в школе (2007), No. 6, p. 4-7.

32 A.B. Филиппов, Новейшая история России: 1945-2006 гг.: Книга для учителя (Москва: Просвещение, 2007); А.А. Данилов/ А.И. Уткин/ А.В. Филиппов (ред.), История России. 1945-2007: Учебник для 11 класса (Москва: Просвещение, 2007). 
which Joseph Stalin was praised as one of the best leaders in Russian history. Reportedly, this textbook was ordered by the Presidential Administration ${ }^{33}$ - the guess confirmed by the fact that Vladislav Surkov, the then-head of the Administration, actively promoted its publication and presentation. But the picture was more complicated as other groups from the circles around President Putin actively objected this pro-Stalinist trend and promoted the liberal textbook edited by Andrei Zubov instead. ${ }^{34}$ Evidently, there was no clarity about what Vladimir Putin meant to be "historical objectivity". Acting in his preferred style, Putin chose to leave even his closest aides unclear about what he really had in mind and how his words should be finally interpreted.

The first normative fixation of the official memory politics took place under the presidency of Dmitry Medvedev, who favored a more explicit style of political communication than his tandem partner Vladimir Putin. On the eve of the Victory Day in 2009, he openly criticized the memory politics of the Central-European countries and deplored that "the attempts to falsify history are becoming increasingly cruel, evil and aggressive". ${ }^{35}$ Several days after this narrative had been posted online, he created the Presidential Commission against falsification of history. ${ }^{36}$ Among the tasks of this Commission was "to collect and to systematize the information about falsification of historical facts made to the prejudice of Russia's international prestige" and to propose to the President measures to counteract falsifications of true history. Medvedev was apparently happy with his idea to create the official version of "true history"; in 2010, he at length described his own views on the Soviet history and confirmed his resolution to fight against distortions of historical events. ${ }^{37}$

However, his ardor stalled over the time - putatively, in the perspective of the coming 2012 elections when it was still unclear whether Putin would rotate back to the presidency. In 2011, Medvedev changed his tonality and, while speaking before Russian teachers in Vladimir about "consensus points" in history, he insisted that this consensus should not be imposed through administrative means. ${ }^{38}$ In February 2012, he cancelled the 2009 Decree and disbanded the Commission against falsification. ${ }^{39}$

33 Исторический припадок, Коммерсанть Власть (16.7.2007), https:/www.kommersan t.ru/doc/782464.

34 А.Б. Зубов (ред.), История России. ХХ век (Москва: АСТ, 2009).

35 РФ создает комиссию по попыткам фальсификации истории, https://ria.ru/20090519/1 71517015.html.

36 Указ Президента Российской Федерации (15.5.2009, №.549) “О Комиссии при Президенте Российской Федерации по противодействию попыткам фальсификации истории в ущерб интересам России" [Decree of the RF President "On the Presidential Commission to Counteract Attempts to Falsify History to the Detriment of Russia's Interests"].

37 Нам не надо стесняться рассказывать правду о войне - ту правду, которую мы выстрадали, Известия (7.5.2010), http://izvestia.ru/news/361448.

38 Президент РФ Д.А. Медведев. Встреча с учёными-историками. Владимир. 22 июля 2011 гг., http://news/12073.

39 Указ Президента РФ (14.2.2012, No.183) “Об утверждении состава Комиссии при Президенте Российской Федерации по формированию и подготовке резерва управленческих кадров, изменении и признании утратившими силу некоторых актов Президента Российской Федерации“" [Decree of the RF President "On the Confirmation of the Composition of the Presidential Commission for the Preparation of the Reserve of Managers, on the Amendment and Repeal of Some Acts of the President of the RF"]. 
Nevertheless, Medvedev's experiments left their imprint on memory politics in Russian law and partly prefigured its development during Putin's third presidency after 2012. In that timespan an array of the repressive laws mentioned above was adopted, and also the state took over the ideological control over schools. In 2012, the Ministry of Education of the Russian Federation obtained the right to impose binding unified standards on the form and contents of schoolbooks. The 2013 standard reflected a more nationalist and exceptionalist spirit of governmental memory policies. ${ }^{40}$

It comes as no surprise that the 2013-2014 patriotic turn in Russia's political agenda was appreciated differently by conservative and liberal forces: the pro-Schmittean philosophers and the Russian Orthodox Church or liberal economists and pro-Western ideologists in the Kremlin. Apparently, these forces and a sundry of other actors had and still are having - impact on the formation of governmental approaches to memory politics which thereby is not monolith. ${ }^{41}$ On the one hand, the educational standards with exceptionalist background were enthusiastically saluted by such leaders of Russian conservatism as Patriarch Kirill, who in 2014 acknowledged the active role of the Russian Orthodox Church in drafting textbooks on history and expressed the hope that the new memory politics would help to eradicate the "syndrome of historical masochism that has been cultivated up at Russian schools in the 1990s". ${ }^{42}$ On the other hand, at the same time, this conservative backlash in school education was opposed by liberal experts and policymakers in and around the government. ${ }^{43}$

In the anticipation of the Ukrainian revolution of 2013, the Russian authorities decided to strengthen the nationalist spirit of school education and initiated discussions about amendments into the textbook standards of 2013. President Putin openly took part in the debates around these amendments, while the Head of the Presidential Administration Sergey Naryshkin insisted that new standards shall become a "new social contract concerning the reception of history in the society". ${ }^{44}$ Expectedly, these narratives only gained force in the context of the annexation of Crimea in 2014, when to Russian political leaders the moment seemed to be ripe to restore the historical justice and at the same time to mitigate the danger of importation of color revolutions to Rus$\operatorname{sia}^{45}$

The 2014 amendments to the Law "On the Perpetuation of the Victory of the Soviet People" of 1995 significantly broadened the definition of "Nazis", including into this concept all the groups and individuals that collaborated with Nazis. Several months before, a new Article 354.1 was brought into the Criminal Code of the Russi-

40 Концепция нового учебно-методического комплекса по отечественной истории, http:// www.kommersant.ru/docs/2013/standart.pdf.

41 А.И. Миллер, Роль экспертных сообществ в политике памяти России, Полития (2013), No.4 (71), p. 114-126.

42 Патриарх Кирилл: единый учебник истории поможет преодолеть исторический мазохизм, https://tass.ru/obschestvo/1410442.

43 А.И. Миллер, see fn. 41.

44 Встреча с авторами концепции нового учебника истории, available at: http:// www.kremlin.ru/events/president/news/20071.

45 Address of the President of the Russian Federation to the Federal Assembly in 2014, available at: http://www.rg.ru/sujet/5339/index.html. 
an Federation, which penalized "the rehabilitation of Nazism". ${ }^{46}$ The definition of "rehabilitation" in this amendment became very extensive and included "the dissemination of patently false information about the activity of the USSR in the years of the Second World War" (para.1). Symptomatically, one of the criminal cases opened by Russia's Investigation Committee under this new corpus delicti was against the exdirector of the Ukrainian Institute of National Memory Vladimir Viatrovich, who had insisted on the alternative reading of the common history of Ukraine and Russia from the Middle Ages onward. ${ }^{47}$

The same federal law introduced criminal liability for "the dissemination of information expressing disrespect toward the days of military glory and memory dates of Russia" (para.3) and administrative liability for the same corpus delicti for legal persons in Art. 13.15 of the Code of Administrative Offences of the Russian Federation. ${ }^{48}$ The list of such commemoration days under the Federal law of $1995^{49}$ is quite extensive: more than thirty dates including the Baptism of Russia (988), days of medieval battles, or the day of the October Revolution of 1917. Practically, the introduction of criminal and administrative liability for disrespect of memory days and days of military glory penalized negative interpretations of a number of historical events which are not in line with the governmental patriotic interpretation.

As mentioned above, the myth of the Great War is among the central axes of the governmental memory policies both in Soviet and in post-Soviet Russia. In the framework of the conflict with the West around Ukraine from 2014 onward, Russia readily resorted to the symbolic value of the Great Victory. In March 2015, President Putin underscored that falsifications of history of the Second World War should be prohibited as "undermining the moral authority of Russia". ${ }^{50}$ Several days thereafter, he created the governmental foundation "History of Homeland", 51 that was charged to promote the patriotic reading of Russian history, especially among the young generation. This symbolic step was followed by a number of other indirect practical initiatives of the Kremlin which very well fit the general exceptionalist and conservative political agenda of contemporary Russia.

\section{Conclusion}

As demonstrated in this paper, anti-Nazism rhetoric has become the key message in governmental policies and strategies dealing with the past. This fact is not accidental,

46 Федеральный закон (5.5.2014, No.128-Ф3) “О внесении изменений в отдельные законодательные акты Российской Федерации" [Federal Law "On Bringing Amendments in Some Legislative Acts of the RF'].

47 https://www.interfax.ru/russia/654174.

48 The Criminal Code of the Russian Federation is applicable only to natural persons; legal persons are punished under the Code of Administrative Offences of the Russian Federation.

49 Федеральный закон (13.3.1995, No.32-Ф3) “О днях воинской славы и памятных датах России" [Federal Law "On Days of Military Glory and Memory Dates of Russia"].

50 Заседание Российского оргкомитета Победа, available at: http://kremlin.ru/catalog/keyw ords/117/events/47867.

51 Указ Президента (6.4.2015, No.163) “О создании фонда История Отечества” [Decree of the RF President "On the Establishment of the Foundation "History of Homeland"']. 
but rather reveals and develops the centuries-old ideological narrative of messianism. Nicholas (Nikolai) Berdyaev aptly characterized Russians as millennial people; ${ }^{52}$ this characterization apparently very well fits to Russia's intellectual history. The main function of the anti-Nazism memory policy is to coin the symbolic axis around which the national identity of Russians is constructed. Russia had the messianic role in the world history - to save mankind from Nazism, and Russia still reasserts itself in this messianic calling to lead the fight against the evil. In the collective mind, this reinterpretation of the old Russian discourse replaces the outdated narratives about Russia's vocation to protect the true religion, and to come close to the Kingdom of God, or to bring about the world socialist revolution and to do away with injustice in the world. Using the old patterns of ideological narratives about Russia's exceptional vocation in the world history (to fight against the evil in the form of false religions or class domination), the new memory politics of Russian authorities seeks to fill up these patterns with actualized content which can be a smart tool of soft power not only inside Russia, but also abroad.

Employing the great narrative of the Second World War as the key idea of memory politics, the Kremlin apparently seeks to revitalize this messianic narrative and to thereby promote the national self-identification of Russians around the axis of evil/ good on the one hand. This new cornerstone of Russian politics is protected, from the mid-2010 s, by the legislation which, on the other hand, echoes Russia's exceptionalist narratives in its relations with the West.

This messianic narrative is also employed in the foreign agenda: at the international level Russia actively propels its reading of history in what concerns the Second World War. In such cases as Kononov vs Latvia (ECtHR, No. 36376/04), and in a number of other controversial cases, Russia utilized not only its financial resources (e.g., paying lawyers for $\mathrm{Mr}$ Kononov) but also its media and diplomatic sources to assert its memory policy in Europe and in the world. The 16.11.2017 Russian-drafted UN resolution [A/C.3/72/L.56/Rev.1] against the glorification of Nazism was considered as one of the important victories of Russian diplomacy. ${ }^{53}$ This trend is actively supported by Russia Today and other Russian media working outside the country, and confirms the general line of the Russian authorities to focus their memory politics on the messianic context of the narrative about the Great War, utilizing this message as the pivotal axis for patriotic education, for the utilization of soft power in foreign relations and, more generally, in coining the framework for national identity.

52 N. Berdyaev, Russian Idea (New York: The Macmillan Company, 1948), p. 193. On this particularity of Russian political thinking, see: D.G. Rowley, Redeemer Empire: Russian Millenarianism, The American Historical Review (1999), No. 5(104), p. 1582-1602.

53 В ООН поддержали резолюцию России по ликвидации нацизма, https://rg.ru/2018/11/ 15/v-oon-podderzhali-rezoliuciiu-rossii-po-likvidacii-nacizma.html. 